\title{
Present Ecological Status and Diversity of Zeuxine Lindl. a Botanically Less Known Orchid of Dibrugarh District of Assam, North East India
}

\author{
Khyanjeet Gogoi $^{1, *}$, R. L. Borah ${ }^{2}$, Raju Das ${ }^{3}$, Raje ndra Yonzone ${ }^{4}$ \\ ${ }^{1}$ Daisa Bordoloi Nagar, Talap, Tinsukia, 786156, Assam, India \\ ${ }^{2}$ Dept. of Botany, DHSK College, Dibrugarh, 786001, Assam, India \\ ${ }^{3}$ Nature's Foster, P.Box 41, Shastri Road, P.O. Bongaigaon, 783380, Assam, India \\ ${ }^{4}$ Dept. of Botany, St. Joseph's College, P.O. North Point, District Darjeeling, W. B., 734104, India
}

\begin{abstract}
Assam is the second largest state of North-East India and treasure trove of Indian orchids. Dibrugarh District is in the located in the eastern part of the state with rich native orchid species. This report is the outcome of our intensive field studies carried out during 2006 - 2011. We have chosen opportunistic method to cover all representative areas of different habitat. We have surveyed the area covering all the seasons of the year. For microhabitat structure randomly selected quadrat of $5 \mathrm{mx} 5 \mathrm{~m}$ were laid in the field and noted down all the features. In this study a total of 114 Orchid species under 54 genera have been recorded from the district. The study revealed 29 species as terrestrial and the rest 85 species are epiphytic. Among the terrestrial genus Zeuxine is found as ecologically and taxonomically complex group of Orchidaceae. During this field study, 6 species of the genus Zeuxine were recorded viz. Z. clandestine; Z. glandulosa; Z. goodyeroides; Z. longilabris; Z. nervosa and $Z$. Strateumatica. The present study envisages the threat and status of these species with conservation recommendation. Moreover, this is the first attempt to establish the taxonomic identification to workout currently accepted botanical names of the genus with its ecological status, voucher specimen numbers, habitat, phenology and distribution in this district.
\end{abstract}

\section{Keywo rds Zeuxine, Present Status, Diversity Resources, Dibrugarh District, Assam}

\section{Introduction}

Zeuxine is an annual terrestrial or rarely lithophytic herbs. The plant usually have elongate, creeping, fleshy rhizome with several nodes. The root is cylindric and stout, that emerge out from these nodes. Stem erect or ascending, terete, leafy and glabrous. Leaves cauline or sub-rosulate, adaxially green to blackish, sometimes with a white stripe along midvein, linear-lanceolate, obliquely ovate-lanceolate, or elliptic, with or without a petiole-like base, sheathing stem, sometimes slightly fleshy. Inflorescence glabrous or pubescent, with a few crowded to scattered sheathing bracts and a few or many flowers in a short to elongate terminal raceme. Flowers resupinate or erect, small, not opening widely; ovary twisted, glabrous or pubescent. Sepals free, similar, outer surface glabrous to pubescent; dorsal sepal concave, forming a hood with petals; lateral sepals enclosing base of lip. Petals connivent with dorsal sepal, nearly as long as dorsal sepal though usually narrower; lip usually adnate to column marg in at base. Column short, dilated; anther ovoid,

* Corresponding author:

khyanjeetgogoi@gmail.com (Khyanjeet Gogoi)

Published online at http://journal.sapub.org/plant

Copyright (C) 2012 Scientific \& Academic Publishing. All Rights Reserved 2-locular; pollinia 2. Capsule erect.

The genus Zeuxine is a taxonomically complex group of Orchidaceae, established in the year 1826 by John Lindley in the appendix to his Collectanea Botanica.

About 80 species are generally distributed in the tropical and South Africa, through tropical and subtropical Asia, to New Guinea, NE Australia, and the SW Pacific islands and China.

\subsection{Study Area}

Dibrugarh District is located in eastern part of Assam, India, with an area of $3381 \mathrm{sq} . \mathrm{km}$. The district extends from $27^{\circ} 5^{\prime} \mathrm{N}$ to $27^{\circ} 42^{\prime} \mathrm{N}$ latitude and $94^{\circ} 33^{\prime} \mathrm{E}$ to $95^{\circ} 29^{\prime} \mathrm{E}$ longitude. It is bounded by Dhemaji district on the north, Sivasagar district on the south, Tinsukia district on the east and Lakhimpur district on the west. The area stretches from the North bank of the mighty Brahmaputra river, which flows for a length of $95 \mathrm{~km}$. through the northern part of the district to the Patkai foothills in the south. At the foothills the altitude is $200 \mathrm{~m} \mathrm{MSL}$ and the Burhidih ing river bank is $99 \mathrm{~m}$ MSL. The area under forest in this district is 217941.648 hectares. Among the protected areas, there are five reserve forests in the district, namely Joypore with 10876.68 hectares[10, 11], Jokai with 1848.01 hectares[2], Namdang 
with 1858.63 hectares, Telpani with 1332.288 hectares and Dih ingmu kh with 5879.04 hectares.

The Joypur Reserve forest forms a part of the world heritage of tropical/sub-tropical wet evergreen forest, classified as $1 \mathrm{~B} / \mathrm{CI}[4]$. The multi layered canopy of the forest is rich in both floral and faunal biodiversity. Considering the vegetation type this forest is known as the only 'Rain forest' in the state. This forest is great reservoir of orchid germplasm due to its high rainfall, relative humidity and light penetration[10,11].

Among the other forest areas Jokai, Namdang, Telpani and Dihingmukh are having mixed forest with evergreen patches, typified as $3 / 152$ and $4 \mathrm{D} / \mathrm{SSI}[4]$. All these forests are close to the bank of river Buridihing or touching it.

\subsection{Climate}

Dibrugarh District has unique physiographic elements, the area experiences subtropical monsoon climate with mild winter, warm and humid summer. The maximum rainfall is in summer $(2740 \mathrm{~mm}-3640 \mathrm{~mm})$ and the minimum rain fall is during winter $(430 \mathrm{~mm}-700 \mathrm{~mm})$. The maximu $\mathrm{m}$ te mperature ranges between $33^{\circ} \mathrm{C}$ to $37^{\circ} \mathrm{C}$ and minimum temperature between $8^{\circ} \mathrm{C}$ to $10^{\circ} \mathrm{C}$. The climate can be distinctly classified into four seasons i.e. Winter, set in the November and lasts upto January followed by Pre- Monsoon period From March to May, when temperature start rising; Monsoon sets during June-July and lasts upto to August - September and Retreating monsoon that starts from last week of September or first week of October the monsoon starts retreating until winter arrives.

\section{Materials and Method}

The intensive field survey work was carried out during 2006 - 2011 covering all the seasons of the year in all parts of forest areas of Dibrugarh district of Assam. In each of the forest areas we used quadrat method to enumerate the habitat. For the diversity of the species we preferred the opportunistic method according to the habitat criteria. Moreover, during this study we have used pre-designed datasheet covering all the parameters like humidity, light intensity, as well threats and micro habitat. We have collected the specimen with flowers and mounted it into herbarium following standard methodologies of Jain \& Rao[14]. We have taken extra care to photographs the live species in field with its habitat. From the collected specimen we have drawn the sketches and describe them following standard protocol of taxono mic description. During the field study we have noted down the phenophases of all the species encountered. The collected samples were compared and consulted with the publication on local, national and international floras like Orchid Flora of KamrupDistrict[1]; The genera and species of Orchidaceous plants[18]; Folia Orchidacea[17]; The orch ids of the Sikkim Himalayas[15]; A Guide to the Orchid of Sikkim[3]; The Orchids of
Thailand[24]; The Orchid Flora of North-West Hima laya[9]; Indian Orchids Guide to Identificationand Culture[22]; Orchids of Mussoorie[23]; Orchids of Arunachal Pradesh[12]; Flora of British India[13]; Orchids of Kumaun Himalaya[20]; A Catalogue of Indian Orchids [16]; Orchids of Nagaland[8]; Orchidaceae of Arunachal Pradesh[6]; Orchid Flora of Arunachal Pradesh[5]; 100 Sikkim Himalayan Orchids[21]; Orchids of India[19]. Specimens were matched at the herbarium of department of Botany Gu wahati University and Botanical Survey of India, Eastern Circle, Shillong (Assam herbarium). Finally all the Voucher specimens have been deposited in the Herbaria of department of Botany, Guwahati University. All the species were arranged systematically with botanical names, habitat, local distribution and flowering month. For study of the microhabitat, randomly selected quadrat of $5 \mathrm{mx} 5 \mathrm{~m}$ were laid in the field.

\section{Results and Discussion}

The climatic condition of Dibrugarh district of Assam of North East India is most congenial for the lavish growth and development of wide varieties of Orchid species in natural habitat. During the field surveys, six species of Zeuxine were recorded. Among these Z. glandulosa is found to be endangered and new report for Assam, and other species viz., $Z$. clandestine and $Z$. longilabris is endangered, $Z$. nervosa is vulnerable, $Z$. goodyeroides and $Z$. strateumatica are found in abundant throughout the district.

It is observed that the genus Zeuxine grow well in humus rich soil and shady places and some species grow well in grassland. The undisturbed forest habitat is found ideal for its lavish growth and development. The genus is not only ecologically important but due to their small beautiful flowers it also has immense floricultural importance too. But the rampant destruction of forests causing greater harm in the natural population of this botanically less known beautiful Orchid Zeuxine in the state of Assam.

Key to the species

1a. Leaves linear to linear-lanceolate, not stalked, base directly

sheathing stem. 6. Z. strateumatica

1b. Leaves ovate-lanceolate to oblong-

lanceolate, base contracted into a

petiole-like stalk sheathing stem.

2a. Leaves blackish- purple, oblonglanceolate...................2. Z. glandulosa

2a. Leaves not blackish- purple, ovatelanceolate.

3a. Column with lamellate wings.

4a. Ep ichile of lip transversely dilated but as broad as or narrower than hypochile, entire to shallowly 2-lobed. 3. Z. goodyeroides $4 \mathrm{~b}$. Ep ichile of lip dilated, broader than hypochile, 
distinctly 2-lobed. 5. Z. nervosa

3b. Column without any appendage. 5a. Lip toothed on the outer margin, mid lobe 2- winged, elongate..................4. Z. longilabris 5b. Lip not toothed on the outer margin, sessile, base saccate, enclosing a simple and conical callus on either side. 1. Z. clandestine

\section{Enumeration}

Zeuxine clandestina Blume, Coll. Orchid. 70. 1858; Barua, Orch. fl. Kamrup Dist. 56. 2001; Mishra, Orch. India 320. 2007.

Plant $10-15 \mathrm{~cm}$ tall, stems and peduncles glabrous. Leaves $2-4,3-4 \times 2 \mathrm{~cm}$, linear, glabrous, 3 nerved, sheathed, scarious. Inflorescence spikes, 8 - 10 flowered. Flowers completely resupinate, sessile, pin kish-wh ite; sepals with prominent midrib, puberulous, pinkish. Dorsal sepals ovate, obtuse, $2.5 \times 2.0 \mathrm{~mm}$; lateral sepals ovate lanceolate, broadly acute, $2.7 \times 1.2 \mathrm{~mm}$. Petals $2.7 \times 1.0 \mathrm{~mm}$, dimid iate, obliquely ovate, narrowed at base, obtuse, white. Lip $2.8 \times$ $2.5 \mathrm{~mm}$, sessile, base saccate, enclosing a simple and conical callus on either side; Colu mn without any wing or appendage. Pollin ia pyriform, granular.

Habitat: Growing in dense forest, cool and shady place. Voucher specimen: Gogoi et al., 0508. Flowering: JanuaryMarch. Local distribution within Dibrugarh district: Jeypore. Present ecological status: Endangered.[Figure 1.]

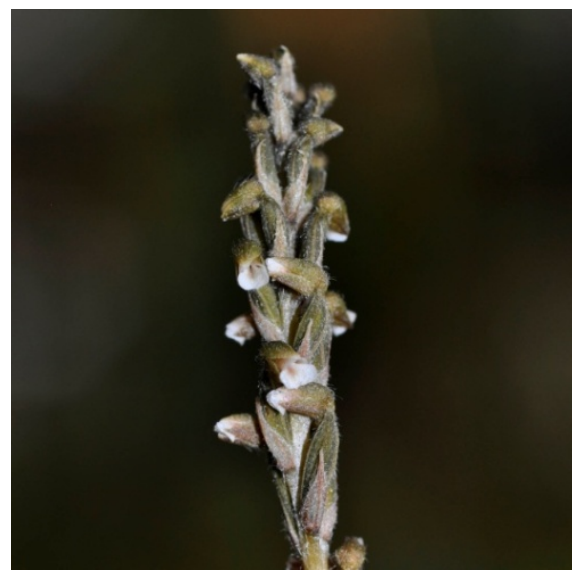

Figure 1. Zeuxine clandestina Blume

Zeuxine glandulosa King \& Pantling in Ann. Roy. Bot. Gard. (Calcutta) 8: 288. t. 384. 1898; Pradhan, Indian Orchid-I: 118. 1969; Mishra, Orch. India 320. 2007.

Terrestrial, $5-20 \mathrm{~cm}$ high. Leaves oblong - lanceolate, acute, shortly petiolate, $2.5-5 \times 0.6-1 \mathrm{~cm}$, blackish-purple; petiole expanded into a wide hyaline sheath. Inflorescence laxly few flowered; peduncle short, pubescent; rachis densely glandular- pubescent, $2.5-3 \mathrm{~cm}$ long. Flowers 0.5 $\mathrm{cm}$ long olivegreen, column and central contracted part of lip white. Sepals connivent, subsimilar, ovate, acute, subequal, sparsely glandular-pubescent, $0.5 \mathrm{~cm}$ long. Petals asymmetrically suborbicular, suboblique, apiculate, $0.5 \mathrm{~cm}$ long. Lip about as long as the sepals, widely saccate at base, middle part curved inwards and white; the interior of sac with row of 3 lamellate calli on each side and an incurved conical tooth on each marg in, $0.5 \mathrm{~cm}$ long. Colu $\mathrm{mn}$ with very large lamellate wings at base, porrect, incurved; rostellum projecting, broad. Pollinia pyriform, bifid, groved; stigmas 2, small, linear- oblong.

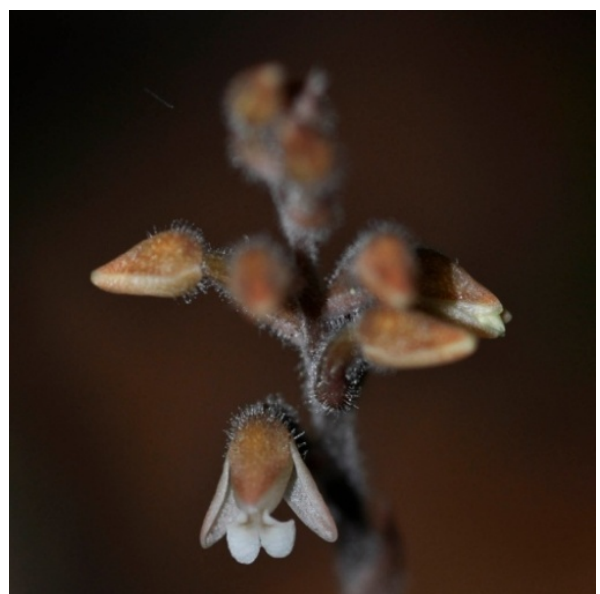

Figure 2. Zeuxine glandulosa King \& Pantling

Habitat: Growing in dense forest, cool and shady place. Voucher specimen: Gogoi et al., 0511. Flowering: MarchApril. Local distribution within Dibrugarh district: Jeypore. Present ecological status: Endangered.[Figure 2.]

Zeuxine goodyeroides Lind1. Gen. Sp. Orchid. 486. 1840; Hook. f., Fl. Brit. India 6: 107. 1890.

Plant $15-27 \mathrm{~cm}$ tall, sheaths $0.7-1.1 \mathrm{~cm}$, clasping. Leaves $3-5,2.6-4 \times 1.2-2 \mathrm{~cm}$, oblong-ovate, acute, shortly petiolate. Inflorescence laxly many flowered, $4-10 \mathrm{~cm}$ long, ridged, sparsely pubescent, with 1 or 2 linear-lanceolate sheaths. Flowers $5-6 \mathrm{~mm}$ long, pink-white, lateral sepals green; pedicellate-ovary sessile, $6-8 \mathrm{~mm}$ long. Sepals subsimilar; dorsal sepal 3.9 - $5 \mathrm{~mm}$ long, ovate, acute; lateral sepals $3.8-5 \times 1.3-1.6 \mathrm{~mm}$, narrowly lanceolate, spreading. Petals 3.9 - 5mm long, white, falcate, subacute, connivent. Lip $3.9-5 \mathrm{~mm}$ long, basally saccate, bidentate within; apex small, with incurved margins. Column $3 \times 3 \mathrm{~mm}$, broad, margins winged below. Pollinia clavate; stigmas oval, lateral.

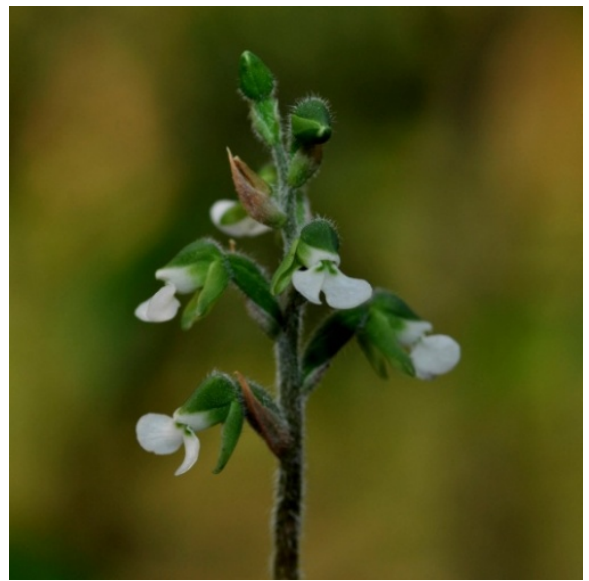

Figure 3. Zeuxine goodyeroides Lindl 
Habitat: Growing in dense forest, cool and shady place. Voucher specimen: Gogoi et a1., 0483. Flowering: JunuaryFebruary. Local distribution within Dibrugarh district: Jeypore. Pres ent ecological status: Common.[Figure 3.]

Zeuxine longilabris (Lind1.) Trimen, in Joour. Ceylon Br. Roy Asiat. Soc. 9: 90. I885; Hook. f., Fl. Brit. India 6: 107. 1890; Chowdhery, Orch. Fl. Arunachal Prad. 695. 1998.

Plant $15-20 \mathrm{~cm}$ tall. Leaves $2-3 \times 1-2 \mathrm{~cm}$, ovate to ovate-oblong, acute, 5 - 7 nerved, drooping, copper-brown white, shortly petioled. Inflorescence terminal, fewflowered, $2-6 \mathrm{~cm}$ long, glandular-pubescent racemes on elongate, slender, purple scapes. Flowers greenish-white; sepals green, broad, obtuse, pubescent. Dorsal sepal deltoid-ovate, obtuse, $6 \times 2 \mathrm{~mm}$; lateral sepals falcately oblong $4-5 \times 1.4-1.6 \mathrm{~mm}$. Petals appressed to the dorsal sepal, falcately oblong, white, $6 \times 2 \mathrm{~mm}$. Lip white, longer than the sepals, $11 \mathrm{~mm}$ long; mid lobe 2-winged, elongate, toothed on the outer margin. Column without any appendage. Pollin ia pyriform, clavate.

Habitat: Terrestrial, growing in grass land. Voucher specimen: Gogoi et al., 0509. Flowering: March -May. Local distribution within Dibrugarh district: Jeypore. Present ecological status: Endangered.[Figure 4.]

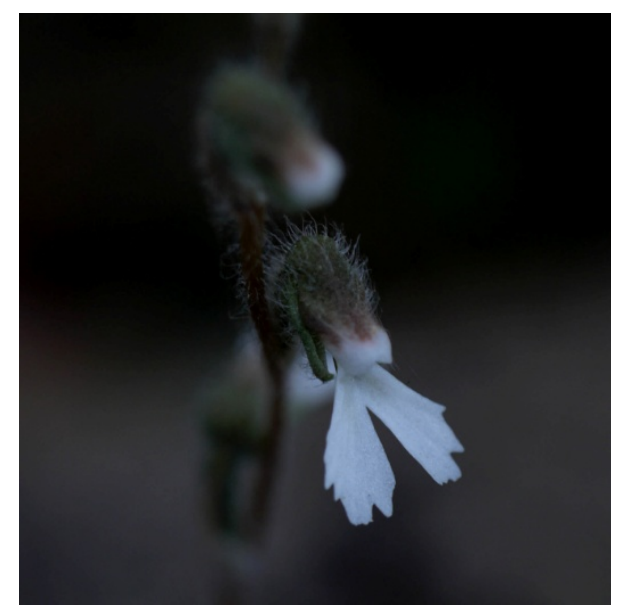

Figure 4. Zeuxine longilabris (Lindl.) Trimen

Zeuxine nervosa (Wall. ex Lind1.) Benth. ex Trimen, J. Ceylon Branch Roy. Asiat. Soc. 9: 90. 1885.

Plants 20 - $35 \mathrm{~cm}$ tall, slender, 3 - 6-leaved. Leaves clustered at stem apex, not usually withering at anthesis, ovate to ovate-elliptic, $4-6 \times 1.5-2.5 \mathrm{~cm}$, apex acute. Inflorescence $18-28 \mathrm{~cm}$, with 2 or 3 widely spaced sterile bracts, sparsely villous, many flowered. Flowers fragrant, resupinate, weakly spreading, s mall. Sepals reddish brown to yellowish green, glabrous; dorsal sepal ovate, concave, 5 $5.5 \times 4.5-5 \mathrm{~mm}$, apex acute or subacuminate; lateral sepals oblong-ovate, $6-6.5 \times 3.5 \mathrm{~mm}$, apex acute to obtuse. Petals white, ovate, oblique, $5.5 \times 3.2 \mathrm{~mm}$, glabrous, apex obtuse; lip white or pale yellow, Y-shaped. Column $2.2 \mathrm{~mm}$; wings prominent, broadly triangular.

Habitat: Damp places in forests. Voucher specimen: Gogoi et al., 0713. Flowering: January-March. Local distribution within Dibrugarh district: Jeypore. Present ecological status: Vu lnerable.[Figure 5.]

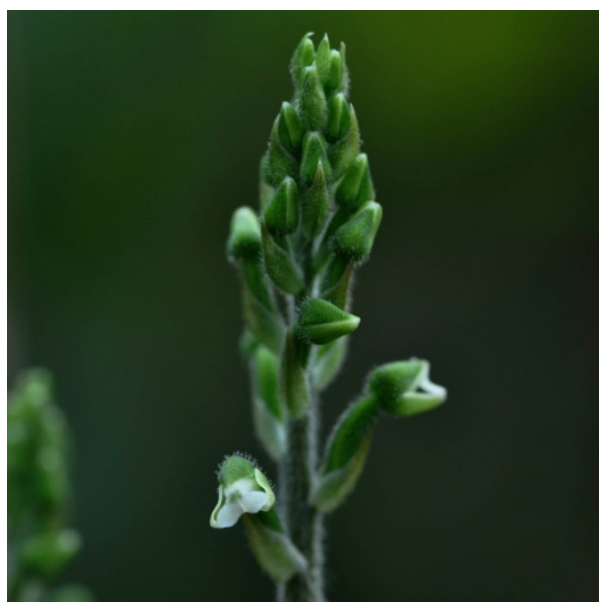

Figure 5. Zeuxine nervosa (Wall. ex Lindl.) Benth. ex Trimen

Zeuxine strateumatica (Lindl.) Sch lechter in Engler, Bot. Jahrb. 45: 394. 1911; Chowdhery, Orch. Fl. Arunachal Prad. 695. 1998; Barua, Orch. fl. Kamrup Dist. 54. 2001.

Plants $4-24 \mathrm{~cm}$ tall, slender, erect, leafy. Leaves $2-8 \times$ $0.2-0.6 \mathrm{~cm}$, cau line, usually clustered and overlapping, pale brown, linear to linear-lanceolate, base directly sheathing stem, apex acu minate. Inflorescence $2-7 \mathrm{~cm}$ long, glabrous, with a few to more than 20 densely arranged flowers. Flowers $5-6 \times 2.8-3 \mathrm{~mm}$, resupinate, white or pale purple white, s mall. Sepals glabrous; dorsal sepal $4-6 \times 2-3 \mathrm{~mm}$, narrowly ovate-oblong, concave, 1-veined, apex obtuse; lateral sepals $4-5.5 \times 1.5-2.5 \mathrm{~mm}$, obliquely oblong, 1 -veined, apex acute or obtuse. Petals $4-5.5 \times 1.5-2 \mathrm{~mm}$, subovate to obovate, oblique, glabrous, 1-veined, apex obtuse. Lip 4-5mm long, pale yellow to yellow, cy mbiform, 3- partite. Column $1.5 \mathrm{~mm}$ long; wings longitudinally oblong.

Habitat: Terrestrial, growing in grass land. Voucher specimen: Gogoi et al., 0024. Flowering: January-March. Local distribution within Dibrugarh district: Namdang, Telpani and Dihingmukh. Present ecological status: Common.[Figure 6.]

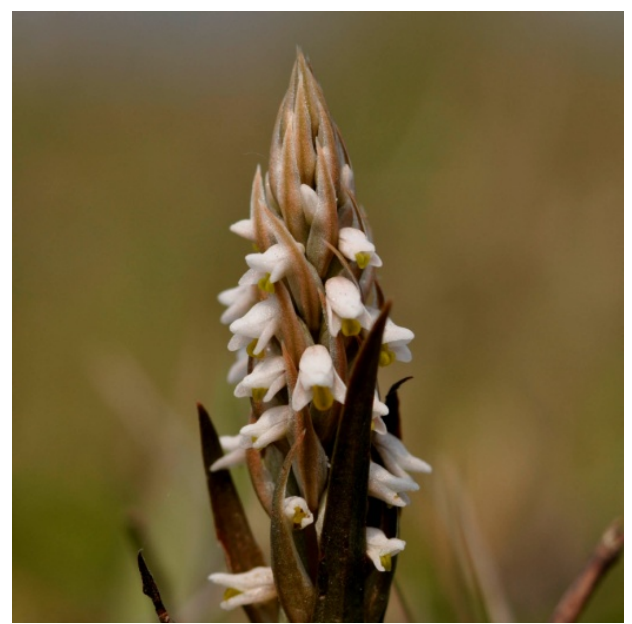

Figure 6. Zeuxine strateumatica (Lindl.) Schlechter 


\section{Conclusions}

There was little information on the taxonomic and ecological status of Zeuxine in Assam. This study enable to fill the gap for its proper taxonomic treatment in local flora. Moreover, the conservation of this species is considered as major priority. For conservation of orchid species the habitat need to be conserve. But due to socio political condition in the past few decades and illegal tree felling, large scale destruction of forests has been resulted in a drastic depletion of Orchid species diversity in Dibrugarh district. In this regard, we consider both short term and long term conservation for the orchid species involving both government and non-government agencies. As it was revealed that deforestation has severely affected the biodiversity of Orchids, it is therefore desirable to conserve the precious Orchid flora of this region through ex-situ as well as in-situ conservation methods. The government and non-government organisation must work with individual communities in the fringe to improve the habitat of orch ids in the area. An atmosphere of conservation contagion should be developed around the protected reserve forest areas and community conservation groups could be formed to join the conservation activities. By conducting village level awareness programmes by government departments and NGOs with constant affiliation with department of forest and wildlife in the regions is the only solution to save our praiseworthy Orchid diversity resources of Dibrugarh district.

\section{ACKNOWLEDGEMENTS}

We are very much grateful to Mr. Dinesh Valke, for allowing us to use his photographs of Zeuxine longilabris for this study. We are grateful to Dr. G.C. Sharma, Dept. of Botany Guwahati University, Assam and Department of forest, Dibrugarh, Assam for constant supervision and valuable suggestions during the course of present studies.

\section{REFERENCES}

[1] Barua, I.C, Orchid Flora of KamrupDistrict. Bishen Singh Mahendra Pal Singh, Dehra Dun India, 2001.

[2] Borah, R. L., Gogoi, K. \& Sharma, G. C. A Taxonomic Survey of the Orchid Diversity of Jokai Reserve Forest of Dibrugarh District of Assam, India. Journal of Non- Timber Forest Products, 2010, 17(1): 19-31.

[3] Bruhl, Paul, A Guide to the Orchid of Sikkim. Thacker \& Spink \& Co., Simla, India, 1926.

[4] Champion, H.G. Seth, S.K, A revised study of the forest type of India, Govt. Of India Press, Nasik, India, 1968.
[5] Chowdhery, H.J, Orchid Flora of Arunachal Pradesh. Bishen Singh Mahendra Pal Singh, Dehra Dun, India,1998.

[6] Chowdhery, H.J. Pal, G.D, Orchidaceae of Arunachal Pradesh. Bishen Singh Mahendra Pal Singh, Dehra Dun, India, 1997.

[7] Chowdhery, S, Assam's Flora. Assam Science Technology and Environment Council, Guwahati, Assam, India, 2005.

[8] Deorani, S.C. Naithani, H.B, Orchids of Nagaland. Oriental Enterprises, Dehra Dun, India, 1995.

[9] Deva, Som \& H. B Nathani, The Orchid Flora of North-West Himalaya. Bishen Singh Mahendra Pal Singh, Dehra Dun, India, 1968.

[10] Gogoi, K., Borah R.L. Sharma, G.C, Additions to the Orchid flora of Joypur Reserve Forest in Dibrugarh district of Assam, India in: Pleione, 2011, 5 (1): 65-70.

[11] Gogoi, K.; R. L. Borah \& G. C. Sharma, Orchid flora of Joypur Reserve Forest of Dibrugarh district of Assam, India, in: Pleione, 2009, 3(2): 135-147.

[12] Hegde, S.N, Orchids of Arunachal Pradesh. Govt. of Arunachal Pradesh, Itanagar, India, 1984.

[13] Hooker, J.D, Orchidaceae. In: Flora of British India. L. Reeve and Co., Ashford, Kent. \& VI: 1890, 1 - 198.

[14] Jain, S.K. Rao, R.R, A Handbook of Field \& Herbarium methods. Today \& Tomorrow's Printers \& Publishers, New Delhi, 1977.

[15] King, G. Pantling R. The orchids of the Sikkim Himalayas. Annals of the Royal Botanical Garden Calcutta 8: 1898, $1-342$.

[16] Kumar, Sathish. Manilal, K.S, A Catalogue of Indian Orchids. Bishen Singh Mahendra Pal Singh, Dehra Dun, India, 1994.

[17] Lindley, J, Folia Orchidacea -An enumeration of the known species of Orchids, London, 1852-1855.

[18] Lindley, J, The genera and species of Orchidaceous plants. London, 1830-1840.

[19] Misra, S, Orchids of India. Bishen Singh Mahendra Pal Singh, Dehra Dun, India, 2007.

[20] Pangtey, Y.P. S., S. S. Samant, G.S. Rawat, Orchids of Kumaun Himalaya. Bishen SinghM ahendra Pal Singh, Dehra Dun, India, 1991.

[21] Pradhan, M, 100 Sikkim Himalay an Orchids, Mumbai, India, 2004.

[22] Pradhan, U.C, Indian Orchids Guide to Identificationand Culture. Bharat Lithographing Co.Calcutta, India. Vol- I, 1976.

[23] Raizada, M.B., H.B. Naithani. H.O. Saxena, Orchids of Mussoorie. Bishen Singh Mahendra Pal Singh, Dehra Dun, India, 1981.

[24] Seidenfaden, G, The Orchids of Thailand, Vol.I- IV. The Siam Society, Bangkok, 1962. 